DOI: $10.14746 /$ por.2018.2.13

\title{
KOMICZNA DEGRADACJA HIERARCHII GATUNKÓW LITERACKICH I FIGURY AUTORA W POWIEŚCIACH MIRJANY ĐURĐEVIĆ
}

\author{
Igor Perišić ${ }^{1}$ \\ (Institut za književnost i umetnost)
}

Słowa kluczowe: degradacja, dehierarchizacja, depatriarchalizacja, komizm, satyra, dystopia, powieść detektywistyczna, figura autora, powieści Mirjany Đurđević Keywords: degradation, dehierarchization, depatriarchalization, comic, satire, dystopia, detective novel, figure of the author novels of Mirjana Đurđević

\begin{abstract}
Abstrakt: Igor Perišić, KOMICZNA DEGRADACJA HIERARCHII GATUNKÓW LITERACKICH I FIGURY AUTORA W POWIEŚCIACH MIRJANY ĐURĐEVIĆ. „PORÓWNANIA” 2 (23), 2018. T. XXIII, S. 187-199. ISSN 1733-165X. Przegląd dorobku powieściopisarskiego Mirjany Đurđević ze szczególnym uwzględnieniem wykorzystywanych przez nią matryc gatunkowych pozwolił na sformułowanie w pierwszej części artykułu tezy, że dehierarchizacja gatunków literackich prowadzi do demistyfikacji figury autora. W oparciu o te analizy w drugiej części pracy szczególną uwagę poświęcono elementom satyrycznym i dystopijnym, obecnym w powieści Odlazak u Jolki Palki (Odjazd w Jołki Pałki) i pokazanych na tle całego dorobku serbskiej pisarki, sposobom konstruowania powieściowej postaci „nowej kobiety” oraz - na poziomie ponadtekstowym - figury autorki. Przedmiotem analizy był także sposób prowadzenia fabuły z ironicznym happy endem, co - między innymi - sprzyja dehierarchizacji gatunków literackich, a także dekonstrukcja ciągle żywego w serbskiej kulturze mitu utworu komicznego jako dzieła literackiego o mniejszej wartości artystycznej.
\end{abstract}

Abstract: Igor Perišić, COMIC DEGRADATION OF HIERARCHY OF LITERARY GENRES AND FIGURE OF THE AUTHOR IN THE NOVELS BY MIRJANA ĐURĐEVIĆ. "PORÓWNANIA" 2 (23), 2018. Vol. XXIII, P. 187-199. ISSN 1733-165X. In the first part of the text, the review of Mirjana Đurđevićs novels, with particular emphasis on the genre matrices used by her, allowed to formulate the thesis that the dehierarchization of literary genres leads to the demystification of the author's figure. In the second part of the work special attention was devoted to the satirical and

1 E-mail: perisigor@gmail.com 
dystopian elements present in the novel Odlazak u Jolki Palki (Going to Yolky Palky) on the background of the Serbian writer's achievements, ways of constructing the novelistic "new woman" and - on the over-text level - the person of the author. In addition, it will be observed how the character of the "new woman" is formed in the novel, as well as the plot with the ironical happy end which, among other things, contributes to the dehierarchization of literary genres and the deconstruction of the myth about the comic work as a less valuable piece of art, a myth that is still very much alive in the Serbian culture.

Mirjana Đurđević, serbska pisarka współczesna, porusza się - jak sama wyznaje w notach odautorskich na końcu swoich książek - w obrębie różnych matryc gatunkowych. Autorka ta, najbardziej znana jako serbska (komiczna) Agatha Christie (Sapožničenko 67), napisała osiem powieści detektywistycznych lub, jak sama twierdzi, „parodii powieści kryminalnych” (Đurđević 2012: 253) z inspektor Brudną Harriet w roli głównej: Ubistvo u Akademiji nauka (2002, Zabójstwo w Akademii Nauk), Parking svetog Savatija (2003, Parking świętego Sawwacjusza), Deda Rankove riblje teorije (2004, Teorie ryb według dziadka Ranka), Jacuzzi u liftu (2005, Jacuzzi w windzie), Proi, drugi, treći čovek (2006, Pierwszy, drugi, trzeci człowiek), Čim preživim ovaj roman (2008, Jak tylko przeżyję tę powieść), Leš u fundusu (2012, Trup w magazynie teatralnym) i Odlazak u Jolki Palki (2016, Odjazd w Jołki Pałki). Odrębnej analizie, choć osadzonej w kontekście pozostałych dzieł, zostanie poddany ostatni z wymienionych utworów, będący przykładem udanej kompilacji cech charakterystycznych tego powieściopisarstwa. Stwierdzić jednak należy, że pisząc powieści detektywistyczne, Đurđević nie zamyka się w ścisłych ramach jednego gatunku, lecz wykorzystując komiczny potencjał satyry i antyutopii, dokonuje jego subwersji. Elementy krytyki społecznej pojawiające się w utworach Đurđević i złożoność wykorzystywanych przez nią strategii prowadzą do degradacji hierarchii gatunkowych; mit różnicy między tzw. literaturą niską a tzw. literaturą wysoką w omawianej prozie ulega całkowitemu zniesieniu (Beleslijin 185; Barzut 171).

Poza powieściami detektywistycznymi, których przynależność genologiczną destabilizują elementy komiczne, Đurđević napisała trzy książki: Čuvari svetinje: Istorijska izmotacija u deset iluminacija (2007, Strażnicy świętości: Błazenada historyczna w dziesięciu iluminacjach), Kaja, Beograd i dobri Amerikanac (2009, Kaja, Belgrad i dobry Amerykanin) i Bremasoni (2011). Posługując się określeniem Lindy Hutcheon (Hutcheon 40), można je określić mianem metafikcji/metaprozy historiograficznej (histographical metafiction), gatunku bardzo silnie obecnego w literaturze serbskiej (reprezentowanego między innymi w prozie Svetislava Basary). Za powieść Kaja, Beograd i dobri Amerikanac, która, poza książkami detektywistycznymi, jest najlepiej znana szerszej publiczności, w 2010 roku autorka otrzymała nagrodę im. Mešy Selimovicia przyznawaną najlepszej powieści wydawanej w Serbii, Chorwacji, Bośni i Hercegowinie oraz Czarnogórze. W utworze, który doczekał się dwunastu wznowień i tłumaczenia na język angielski, poza grą faktów historycznych i pseudohistorycznych pojawia się realistyczny, choć ukazany w krzywym zwierciadle obraz 
mieszczańskiego Belgradu z okresu między pierwszą a drugą wojną światową, ze szczególnym uwzględnieniem dzielnicy Vračar, niegdysiejszej peryferii, stanowiącej obecnie ścisłe centrum miasta. Dzięki temu powieść jest udaną i w dużej mierze prawdziwie sentymentalną ewokacją epoki, dość niekonwencjonalną zresztą, bo opartą na demitologizacji wydarzeń istotnych z punktu widzenia oficjalnej historiografii.

W powieści Bremasoni alternatywna historia serbskiej loży masońskiej okresu międzywojennego została opowiedziana za pomocą szeregu twórczych anachronizmów. Do tytułowej loży należą na przykład słynni pisarze serbscy: Borislav Pekić jako dziesięcioletni chłopczyk, Branislav Nušić (pośmiertnie), a także Sima Milutinović Sarajlija, który „zmarł dużo wcześniej” (Đurđević 2011: 115). Paralelnie z tą "oficjalną" lożą, na marginesie głównego nurtu historii działa „apokryficzna” masoneria kobieca. Należy do niej między innymi Sava Damjanov, znany serbski pisarz współczesny, w powieści wcielający się w postać kobiety „nieco lżejszych obyczajów", ale o wesołym usposobieniu, którego zadaniem jest rozgłaszanie w miasteczku plotek na polecenie loży (Đurđević 2011: 30-31). Bremasoni stanowią bardzo udaną mieszankę metafikcji historiograficznej i literatury zaangażowanej, będącą rodzajem kobiecej utopii satyrycznej.

Đurđević jest także autorką utworu noszącego tytuł Čas anatomije na građevinskom fakultetu (2001, Lekcja anatomii na Wydziale Budownictwa), określonego przez nią mianem "pamiętników” (Đurđević 2008: 264) czy też - w innym miejscu - „farsy faktograficznej" (Đurđević 2016: 239). W dorobku tej autorki znalazły się również powieści, opatrzone komiczno-ironicznym dookreśleniem gatunkowym. Powieść Aždajin osmeh (2004, Uśmiech smoka) autorka charakteryzuje jako „męski melodramat współczesny" (Đurđević 2008: 264), a Treći sektor (2001, Sektor trzeci) opisuje jako „wdzięczną belgradzką historię miłosną z dziedziny przestępczości pozarządowej" (Đurđević 2008: 264). Ostrze satyry w ostatnim z wymienionych utworów skierowane jest przeciwko znanym uczestnikom życia społeczno-politycznego. Ich reprezentantką jest kobieta, która zakładając organizację pozarządową, próbuje znaleźć sposób na przetrwanie w nowej rzeczywistości okresu transformacji ustrojowej i przemian demokratycznych w Serbii po roku 2000.

Wraz z Brankiem Mlađenoviciem Đurđević napisała także komiczną powieść Bunker Swing (2013, Bunkier swing). Akcja utworu rozgrywa się w Stanach Zjednoczonych w czasach prohibicji (1920-1933), a jej bohaterami są serbscy emigranci. Główna postać, Anđelka Vajs, po śmierci męża dziedziczy nie tylko jego dom, ale i długi. Autorzy tej powieści umiejętnie rozpisali relacje emocjonalne między Anđelką a trzema mężczyznami, z którymi główna bohaterka dzieli dom: w jednym ze współlokatorów jest zakochana, drugi jest zakochany w niej, a trzeci to niespokojny młodzieniec, postać obdarzona ogromnym potencjałem komicznym. Każdy rozdział rozpoczyna scena werbalnej i fizycznej przemocy, dokonywanej przez bohaterkę nad Tričkiem - obrzucania go nie tylko obelgami, ale także kapcia- 
mi i innymi drobiazgami, jakie wpadają jej w ręce. Komizm gestów i ruchów, którym przepełnione są te obrazy, nawiązuje do tradycji niemych filmów z udziałem Charliego Chaplina. Mieszanka dialektów z południa i północy Serbii, cały arsenał chwytów komicznych oraz swego rodzaju utopijna romantyzacja fabuły sprawiają, że powieść ta godnie wpisuje się $\mathrm{w}$ tradycję, którą w literaturze serbskiej zapoczątkował Stevan Sremac.

Dehierarchizacja gatunków literackich w prozie Đurđević z konieczności prowadzi do demistyfikacji figury autora. Nie jest to nowe zjawisko w historii literatury światowej, możemy je obserwować od Don Kichota Miguela de Cervantesa, poprzez powieści Laurence'a Sterne'a i Jeana Paula aż po literaturę postmodernizmu. W prozie serbskiej pisarki demistyfikacji podlega jednak również kobieca figura autorska. Obdarzając swoim imieniem i nazwiskiem postać literacką, Đurđević czyni jednocześnie $\mathrm{z}$ autorki bohaterkę komiczną obdarzoną wszelkimi ludzkimi wadami i zaletami. Co więcej, degraduje ją wówczas, gdy autorka występuje w roli Wielkiej Plotkary lub Wielkiego Babsztyla. W ten sposób Đurđević sugeruje konieczność powrotu do dyskusji nad figura "rzeczywistego autora”, zagadnienia marginalizowanego przez tradycyjną narratologię. Problem ten porusza Predrag Brebanović w tekście Czy istnieje życie po śmierci. Zdaniem młodego teoretyka literatury teza sformułowana przez Rolanda Barthesa nie oznacza wyeliminowania autora, lecz jego "ponowne odczytanie":

"Na poły proch, na poły bóstwo“, autor - jako podmiot tekstualny, ale w coraz większym stopniu ponownie jako byt biograficzny! - zaczyna zatem ożywać w literaturze, choć jednocześnie, jeśli można tak powiedzieć, jest w niej pod wieloma względami nieobecny (Brebanović 192).

W czasach przesytu poetyką postmodernistyczną, którą powieści Đurđević mimo wszystko ciągle reprezentują, potrzeba ironicznego lub rzeczywistego wskrzeszenia figury autora jest w prozie serbskiej pisarki bardzo widoczna. Sposób jej wyrażania osadzony jest $\mathrm{w}$ feministycznych koncepcjach, postulujących konieczność rewizji ekskluzywnie męskiego autorstwa. Đurđević bawi się nim, dokonując jednocześnie, już całkiem poważnie, dekonstrukcji patriarchalnych modeli narracyjnych, które tę figurę wytworzyły. Pozornie degradując wybrane przez siebie konwencje genologiczne, autorka gra na nosie tradycyjnemu męskiemu kanonowi gatunków literackich.

$* * *$

Prowadząc grę z kontrowersyjnymi „pismami świętymi” serbskiego kanonu literackiego, Đurđević unika jednocześnie możliwości, by powieści pisane przez nią 
w kluczu gatunkowym całkowicie mieściły się w zadanych ramach. Dąży raczej do tego, by w każdym utworze obecne były elementy gatunków pokrewnych lub by dana powieść jednoczyła wszystkie uprzednio wykorzystane przez autorkę tropy i wzorce genologiczne. Tendencja ta obecna jest także w ostatnim jak dotąd dziele pisarki, zatytułowanym Odlazak u Jolki Palki: ili Lažna uzbuna u Aleji zaslužnih (Odjazd w Jołki Pałki: czyli fałszywy alarm w Alei Zasłużonych). Komiczna degradacja, która dokonuje się tu na różnych planach, służy zarazem obaleniu mitu tragizmu jako nieodzownego elementu wielkiego dzieła literackiego.

Już podtytuł sygnalizuje, że oparta na detektywistycznej matrycy gatunkowej powieść reprezentuje literaturę społecznie zaangażowaną: "Aleja Zasłużonych" to nazwa zinstytucjonalizowanej przestrzeni, stanowiącej - także w pozostałych powieściach serbskiej autorki, w których nie tylko miejsca, ale także zjawiska i osoby zyskują symbolicznie rangę Instytucji - ośrodek satyrycznego suspensu. Przykładowo, miejscem jednego z zabójstw w powieściowej serii o inspektor Brudnej Harriet jest Akademia Nauk, a w książce Leš u fundusu miejscem zbrodni jest teatr.

W powieści Proi, drugi, treći čovek występuje zbiegły oskarżony Trybunału Sprawiedliwości w Hadze, przy czym losy zbrodniarzy wojennych, obecnie już osądzonych, stanowią egzemplifikację chorobliwych sposobów działania instytucji, funkcjonujących $\mathrm{w}$ nieodległym okresie serbskiej historii. W powieści Čuvari svetinje ostrze satyry wymierzone jest przeciwko jasnowidztwu (proroctwom), którym w latach dziewięćdziesiątych i w pierwszej dekadzie XXI wieku wiele miejsca poświęcały media publiczne, przyczyniając się w ten sposób do kształtowania sprofilowanego obrazu rzeczywistości. W powieści zostają zdemitologizowane przełomowe momenty historii narodu serbskiego, budowane nierzadko w oparciu nie o fakty, ale o mitotwórcze ambicje jej interpretatorów. Bunker Swing (podobnie jak Parking svetog Savatija) poddaje krytycznemu osądowi zamiłowanie Serbskiej Cerkwii Prawosławnej do pieniędzy, zaś utwór Čim preživim ovaj roman to między innymi parodia systemu opieki medycznej i satyryczny obraz korupcji w publicznej służbie zdrowia.

W swojej prozie Đurđević nie oszczędza także postępowo-liberalnego bieguna sceny politycznej. W szpony satyry serbskiej pisarki dostają się - jako instytucje liberalnego społeczeństwa otwartego - organizacje pozarządowe. W powieści Treći sektor:

Kurczątko [prawdziwe imię: Milica, dwudziestopięcioletnia dziewczyna - I.P.] zatrudniłam jako sekretarza technicznego $\mathrm{z}$ "doświadczeniem zawodowym $\mathrm{w}$ organizacjach pozarządowych". W rzeczywistości w którejś z organizacji feministycznych, zapomniałam, o którą konkretnie chodzi, ale ja je wszystkie nazywam „Kobietami w kolorze” [aluzja do „Kobiet w czerni”, znanej antywojennej feministycznej organizacji pozarządowej I.P.], ponieważ jest to bardzo barwne towarzystwo. Występują w wielu odmianach, więc jeśli im tak bardzo zależy, niech same oddzielają ziarno od plew (Đurđević 2001: 9). 
Zdaniem głównej bohaterki, wszelkie misje, cele, zasady moralne są jedynie frazesami, pod przykryciem których nieznani sponsorzy lokują swój kapitał w celu uzyskania ulg podatkowych.

Powieść Odlazak u Jolki Palki również reprezentuje prozę satyryczną, zaangażowaną społecznie i antyutopijną. „Ёлки naлku!”, jak wyjaśnia autorka w epilogu, to rosyjski „eufemizm zastępujący przekleństwo, jakiekolwiek, byle szpetne. Co daje czytelnikowi możliwość, by czytając lub rozmawiając o tej powieści, mógł używać swoich ulubionych przekleństw" (Đurđević 2016: 237, kursywa pochodzi od autorki powieści). Jeden z nieeufemistycznych wariantów tego sformułowania, a tym samym i tytułu książki, wypowiada główna bohaterka, otrzymawszy propozycję, by wyjechać do Moskwy z ukochanym mężczyzną: „Wyruszyłabym z tym kretynem w pizdu, byle nie do Moskwy" (Đurđević 2016: 234). W ten sposób na poziomie metaliterackim autorka sugeruje możliwość pożegnania z inspektor Brudną Harriet, której udało się dożyć podszytego ironią szczęśliwego zakończenia, z drugiej jednak strony samej Đurđević nie pozostaje nic innego jak tylko pożegnać się ze sceną literacką i wyjechać w „Jołki Pałki”, skoro jej dzieła nie znalazły żadnego oddźwięku.

Ostatnia jak dotąd powieść Đurđević jest odważną satyrą na współczesną rzeczywistość społeczną. W obszernych fragmentach tej antyutopii mowa jest pośrednio o dyktaturze małżeństwa Miloševiciów w niegdysiejszej Federalnej Republice Jugosławii w ostatnim dziesięcioleciu ubiegłego wieku, zabójstwach na zlecenie, za które odpowiedzialność przypisywana jest żonie byłego prezydenta - Mirjanie Marković, ukrytej w powieści pod postacią Kwiaciarki. W ostatnim rozdziale książki zatytułowanym „Przyznaję się” (rozdziały, w których autorka ironicznie lub na poziomie autopoetyki odnosi się do zakończonej właśnie narracji, stanowią jedną z cech charakterystycznych utworów Đurđević) pojawia się wyjaśnienie przyczyny powstania powieści. Bezpośrednim impulsem do napisania książki był opublikowany w 2014 roku tekst publicystyczny na temat ponownego wszczęcia śledztwa w sprawie zabójstwa dziennikarki Dady Vujasinović (zdarzenie z 1994 roku), zaś impulsem pośrednim - wydanie w 2015 roku przez wydawnictwo Kompanija Novosti dwutomowych pamiętników Mirjany Marković pod tytułem To było tak (Bilo je to ovako). W ironicznie wyidealizowanym przez autorkę książki rosyjskim przytułku (sanatorium) - „królestwie kwiatów” (Đurđević 2016: 35) - dotknięta demencją powieściowa Kwiaciarka pisze artykuły i eseje (których nawet w Rosji nikt nie chce opublikować), by wyrazić swoje rozmyte i utopijne, a w istocie niebezpieczne idee, posługując się przy tym łatwo rozpoznawalnym stylem Marković, którego nie trzeba parodiować, wystarczy pastisz:

Z królestwa kwiatów, które wedtug mnie panuje nad nasza planeta, pod moje okno przybywaja pierwsze przebiśniegi. Wysuwaja swoje pochylone szyje, jak gdyby wstydzity się tego, że odwiedzaja mnie w tym kraju, który nie jest mój, a jednak coraz bardziej i bardziej, z dnia na dzień, z nocy na noc coraz bardziej mój. [...] Tęsknię za swoim krajem, w którym jedynie przebiśniegi 
witaja się za mna radośnie, jak z dawna przyjaciótka, wiedząc, że najmilszymi memu sercu gośćmi są ci, którzy zwiastuja wiosnę (Đurđević 2016: 19, kursywa pochodzi od autorki).

Jednym z głównych bohaterów powieści jest Maki, syn Kwiaciarki, w którym bez trudu rozpoznać można syna Marković i Miloševicia, Marka, z powodu swojej przestępczej działalności w ojczyźnie zmuszonego szukać schronienia w Rosji. Jego stosunek do serbskich zbrodniarzy wojennych uczestniczących w konflikcie w Bośni i Hercegowinie ujawnia się w dobitnej odpowiedzi syna na prośbę matki, by zabrał ją do Sarajewa: "Jeszcze nie skończyliśmy” (Đurđević 2016: 122). Jest to aluzja do zadań, wykonywanych tam przez serbskie siły wojskowe i paramilitarne. Za pomocą chwytu rodem $z$ literatury zaangażowanej autorka wskazuje na odpowiedzialność małżeństwa Miloševiciów za wojnę na terenach Jugosławii.

W powieści zostały zdezawuowane także inne instytucje, oszczędzone przez autorkę w innych jej utworach. W moskiewskim Domu Spokojnej Starości, w którym przebywa rosyjska Kwiaciarka, panuje dystopijna atmosfera rodem z prozy George'a Orwella, natomiast opis belgradzkiego domu opieki, w którym mieszka matka Harriet, jest komiczną trawestacją filmu Miloša Formana Lot nad kukutczym gniazdem:

Około dziesięciu staruszek i dwaj - trzej dziadkowie, rozmieszczeni na kanapach, w fotelach i wózkach inwalidzkich oglądają w telewizji Novaka Đokovicia. W skupieniu, z jakim oglądaliby transmisję z parlamentu, Piećdziesiąt twarzy Grey'a czy pogrzeb patriarchy. Przeważnie wbijają wzrok w ścianę, na której znajduje się ekran, jeszcze częściej we własne kolana. Niektórzy drzemią (Đurđević 2016: 117).

W książce pojawiają się też aluzje do aktualnej sytuacji politycznej, na przykład satyrycznie zniekształcony jest $w$ utworze opis działalności będącej obecnie u władzy Serbskiej Partii Postępowej (Srpska napredna stranka) i jej „polityki” powierzania odpowiedzialnych stanowisk niewykształconym kadrom. W miejscowości Vrnjačka Banja Harriet dowiaduje się, że miejscowym burmistrzem jest człowiek wątpliwego morale i jeszcze bardziej wątpliwej kariery, z którym chodziła do szkoły podstawowej:

[...] jaki tam kolega, raczej ofiara losu, która trzydzieści lat prowadzała stare baby na baseny w sanatorium, portier albo coś $\mathrm{w}$ tym guście, pamięta jak przez mgłę, że dawno temu wybuchł nawet skandal, fotografował jakieś kobiety w brodziku, ale po pięćdziesiątce nagle zrobił się postępowy i ekspresowo zdobył prawo do przebywania $\mathrm{w}$ największym biurze budynku przy głównej ulicy (Đurđević 2016: 129).

Pomimo uwikłania we współczesność, powieść Odlazak u Jolki Palki nie staje się, dzięki wykorzystaniu różnorodnych matryc gatunkowych, z których żadna nie dominuje, zaangażowaną powieścią interwencyjną o charakterze publicystycznym. 
Wbrew swojemu wywrotowemu potencjałowi - a może właśnie za jego sprawą - proza Đurđević nie doczekała się jeszcze uznania ze strony mainstreamu literackiego w Serbii. Przypomnijmy, że nagroda imienia Mešy Selimovicia, którą otrzymała autorka, przyznawana jest w Bośni i Hercegowinie, a od otrzymania przez pisarkę nagrody „Kobiece pióro” upłynęło już dużo czasu. W roku wydania powieści Odlazak u Jolki Palki (2016) prestiżowa nagroda czasopisma „NIN" trafiła do Ivany Dimić za powieść Arzamas, podczas gdy Đurđević znalazła się w gronie jedenastu ścisłych finalistów. Obie powieści - ta autorstwa Dimić i ta Đurđević - dotyczą podobnej tematyki (ich bohaterkami są dotknięte demencją staruszki). Chociaż w książce Đurđević jest ona zaprezentowana w sposób bardziej złożony, nagrodę otrzymała Dimić, jak się wydaje, przede wszystkim ze względu na pojawiające się w jej utworze (pseudo)filozoficzne pasaże, odsyłające do konwencji literatury wysokiej. Czy celem autorki powieści Arzamas nie była, ze względu na niecodzienną kompozycję utworu, degradacja hierarchii gatunków literackich? Odpowiadając twierdząco na to pytanie, należy podkreślić, że dokonano jej w sposób znacznie mniej radykalny niż ma to miejsce w książce Đurđević. Dimić zawiera bowiem pakt z wciąż jeszcze dominującym ",akademickim” gustem literackiego establishmentu, który z nieufnością podchodzi do hybrydyzacji gatunków literackich, szczególnie zaś do używania tzw. gatunków popularnych w tzw. literaturze wysokiej.

Đurđević rozprawia się także z mitem dziedziczenia autorytetu twórcy w linii męskiej. Tworząc antymit "niedoskonałej autobiografii”, stojącej w opozycji wobec patriarchalnych wymagań stawianych pisarzom płci męskiej, autorka poddaje degradacji figurę autora-mężczyzny. Nie jest to jednak dekonstrukcja ideologiczna, lecz gra stereotypami płci. Wyśmiewając w powieści Bremasoni męską próżność i walkę o władzę, "autorka czyni ukłon w stronę kobiet, ale czyni to z wdziękiem i żartobliwie, przedstawiając swoje alter ego jako Wielkiego Babsztyla" (Gordić-Petković 2016: 88). Potraktowana w omawianym utworze z sympatią postać Borislava Pekicia nosi cechy komiczne. Jest to pisarz, który już w wieku dziesięciu lat ze „swoich kosmicznych wyżyn" (Đurđević 2011: 40) (wysokość ma tu wymiar zarówno metafizyczny, jak i fizyczny, gdyż rzeczywisty Pekić był osobą słusznego wzrostu) przejawia zatroskanie losem zarówno swojego przyszłego dorobku literackiego, jak i samej loży masońskiej, czyli, w przenośni, wspólnoty i nacji, do której należy. W powieści sparodiowana zostaje także czytelnicza i pisarska hiperproduktywność Pekicia. Taka degradacja ma charakter żartobliwy, a nie ironiczny. Pisarz ten również stawiał sobie za cel destabilizację hierarchii gatunków literackich, pisząc, poza powieściami przynależącymi do tzw. literatury wysokiej, utwory dystopijne z elementami gatunkowymi prozy detektywistycznej i fantastyczno-naukowej (Besnilo - Wścieklizna, Atlantida - Atlantyda i 1999. - Rok 1999). Jeśli ponownie przywołamy wniosek, że Đurđević poddaje degradacji swój status jako pisarki, jasny stanie się fakt, że chodzi tu o działalność planową, mającą na celu zdezawuowanie figury Autora/ Autorki. Zmarły w 1992 roku Pekić (mniej) i Đurđević (bardziej) są 
świadomi, że ich największe osiągnięcia literackie stanowią utwory komiczne, które w tradycyjnej hierarchii wzorców gatunkowych nadal uchodzą za dzieła o mniejszej wartości intelektualnej. Na przykład tom siódmy Złotego runa Pekicia z powodu nadmiernego zaangażowania mitopeicznego należy uznać za utwór mniejszej rangi niż pierwszych sześć tomów tej powieści, nawiązujących do najlepszych tradycji europejskiej literatury komicznej.

Đurđević nie pretenduje do tego, by stworzyć mit pisarki jako głosicielki nowej Prawdy Literackiej. Pisząc o inspektor Brudnej Harriet (protagonistka o tym imieniu stanowi intermedialne i jednocześnie, ze względu na płeć, trawestacyjne nawiązanie do policjanta Brudnego Harry'ego z filmów Clinta Eastwooda) z powieści detektywistycznych Đurđević, Neda Mandić-Spasojević elementy komiczne odnajduje przede wszystkim w strumieniu świadomości bohaterki:

Strumień świadomości tej postaci $\mathrm{w}$ zawrotnym tempie, ale $\mathrm{z}$ wieloma malowniczymi szczegółami, fragmentaryzuje socjologiczne, psychologiczne, historyczne i inne segmenty, wywołując równocześnie śmiech i łzy. [...] Harriet jest wybuchowa, a w jej świadomości dochodzi do szczególnie intensywnej gonitwy myśli. Z tego względu jej wypowiedzi przypominają serie wystrzałów (Mandić-Spasojević 239-240).

Również w powieści Odlazak u Jolki Palki źródłem komizmu jest przede wszystkim główna bohaterka. Inspektor Brudną Harriet charakteryzują przy tym „depresja, niepokój i apatia" (Gordić-Petković 2017: 78), cechy, które same w sobie nie są zabawne, ale pokazane przez pryzmat ciętego i dowcipnego języka bohaterki, z konieczności stają się ironiczno-komiczne. Ponieważ Harriet nie jest w twórczości serbskiej autorki jedyną postacią kobiecą charakteryzującą się cynicznym poczuciem humoru, Jasmina Vrbavac pisze o „grupie bohaterek prozy Đurđević, obdarzonych ciętym językiem" (Vrbavac 172), a w szczególności o Anđelce, protagonistce powieści Bunker Swing, należącej do grupy „silnych, energicznych, pragmatycznych i zdecydowanych kobiet, które w literaturze rodzimej tworzą zupełnie nowy, kobiecy świat [...]" (Vrbavac 173). W książce Odlazak u Jolki Palki Hariett, która starzeje się w kolejnych powieściach, przechodzi nie na jedną, lecz na dwie emerytury, dzięki czemu jej starość ulega komicznej hiperbolizacji. Jako niegdysiejsza pracownica serbskiego MSW Harriet otrzymuje jedną emeryturę, natomiast drugą, amerykańską, załatwia jej były mąż. Pomimo tego młodość tej podwójnej emerytki, osoby, która przeżyła raka piersi (w powieści Jak tylko przeżyję tę powieść), i kiepsko opłacanej tłumaczki literatury kryminalnej, szczególnie w porównaniu z innymi bohaterkami serii: dwiema dotkniętymi demencją Kwiaciarkami, własną matką i powieściową Marković, ujawnia się dzięki błyskotliwemu humorowi, pozbawionemu oznak starzenia się umysłu.

Niemal wszystkie kobiety w powieściach Đurđević funkcjonują niejako poza swoim czasem biologicznym. Osoby fizycznie stare wracają do iluzji młodości, 
natomiast te stosunkowo młode odznaczają się cechami intelektualnymi, za sprawą których bliżej im raczej do osób w średnim wieku. Paradoksalnie u początków twórczości literackiej Đurđević, w powieści Treći sektor, pojawia się postać trzydziestosiedmioletniej, choć chwilami niepoprawnie infantylnej kobiety - Rozaliji Milić, która w młodości podjęła związaną z życiem prywatnym i zawodowym decyzję, by jako osiemnastolatka stworzyć Projekt Urodzenia Dziecka (syna). Uczyniła to po to, by dziecko miało młodą matkę oraz by ojciec, żonaty mężczyzna, nie wtrącał się do wykonania „zadania”. Relacja matka - syn w tej powieści budowana jest na zasadzie perwersyjnej dehierarchizacji patriarchalnej matrycy. Gdy ginie ojciec syna Rozaliji oraz umierają mieszkający z nimi dotąd jego babcia i dziadek, dziecko staje się równoprawnym, a niekiedy nawet dominującym partnerem bohaterki w tej „okaleczonej rodzinie":

Aca i ja jesteśmy sami już od czterech lat. On bardzo mnie kocha. Czasem myślę, że kocha mnie bardziej niż ja jego. A może tylko mądrzej, bardziej inteligentnie? Pozwala mi dorosnąć, uniezależnić się. Na przykład zostawiając mnie, jak dzisiaj, bez kolacji, żebym poradziła sobie sama. Ja też pozwoliłabym mu dorosnąć, tylko że on urodził się dorosły (Đurđević 2001: 30).

Rozalija sprawia wrażenie dziecka swojego przedwcześnie dojrzałego syna. Jednak on, we fragmentach powieści, w których pełni rolę narratora, buntuje się przeciwko narzuconemu statusowi wiecznego dziecka, jaki przypisała mu matka. Stara się zatem przekroczyć granice zwyczajowych norm rodzinnych.

Niezwykłość Harriet przejawia się również w podejmowanych przez nią próbach zdekonstruowania matriarchalnych stosunków rodzinnych. W powieści Odlazak u Jolki Palki bohaterka zostaje "matką" (opiekunką) własnej dotkniętej demencją rodzicielki. W powieściowej relacji między córką a matką uwidacznia się, jak zauważyła Vladislava Gordić-Petković, przewaga cynizmu nad czystym komizmem:

[...] autorka nieco cynicznie prowadzi powieściową intrygę ku tezie o zapomnieniu jako czynniku przemiany osób starszych w bezużytecznych starców, którzy zapominają o przenikliwości umysłu, odpowiedzialności, sensie i logice: demencja w powieści Mirjany Đurđević nie wywołuje efektu komicznego. Jest straszna, groteskowa, ukazana jako nowy sposób wyrażania odwiecznej potrzeby dominacji nad własnymi dziećmi, które, jako podstarzałe i osłabione, nie są w stanie opiekować się rodzicami, a nie opanowały również lekcji troski o samych siebie (Gordić-Petković 2017: 78).

Choć nie ulega wątpliwości, że w utworze Odlazak u Jolki Palki dominuje charakterystyczny dla Mirjany pogodny komizm, to jednak dotknięta demencją matka Harriet, która dzieli z Mirjaną Marković przezwisko, kojarzy się negatywnie. W przeciwieństwie do innych fragmentów książki, opowiedzianych tonem komicz- 
no-sentymentalnym, w relacji matka - córka nie ma miejsca na emocje, stosunek ten zostaje przedstawiony jako inwentaryzacyjny spis życia, które w praktyce już się skończyło. W ten sposób Đurđević wydobywa problem (niepoprawny politycznie, ponieważ to, co komiczne i cyniczne, nieuchronnie wchodzi w konflikt $\mathrm{z}$ ustalonym porządkiem społecznym), geriatriokracji jako „ideologicznej formy” patriarchalnego społeczeństwa.

Na temat sposobów postrzegania kobiet, których za sympatyczne nie uważają przede wszystkim mężczyźni, tj. patriarchalne otoczenie społeczne, wypowiada się w rozmowie z Rozaliją (powieść Treći sektor) jej najlepsza przyjaciółka Mariola: "Zimna. Nadęta. Zgryźliwa. Najmądrzejsza. Nikogo nie potrzebujesz" (Đurđević 2001: 139). Oprócz tych antypatriarchalnych cech, które odnajdujemy już w postaci Rozaliji, Harriet posiada również inne „wady”. Pali, pije piwo i przeklina, gustuje w rubasznym humorze. Ze względu na zadania, które wykonuje jako detektyw, niekiedy musi wcielać się w postać "prawdziwej kobiety”, nie mogąc doczekać się momentu, gdy będzie mogła zrzucić z siebie „niewygodne i tłuste damskie gówno" (Đurđević 2016: 156). Harriet, będąca w pewnym sensie prototypem bohaterki kobiecej w prozie Đurđević, nie pasuje do feministycznego ideologemu „nowej kobiety", choć częściowo i w sposób niekonwencjonalny niewątpliwie go wspiera. Reprezentuje bowiem ty p bohaterki pozostającej w ciągłym konflikcie z patriarchalnymi normami społecznymi. Jest egzemplifikacją tego, kim, według autorki, powieściowa kobieta nie jest, bez potrzeby propagowania tego, kim być powinna.

Znalazł się jednak ktoś, komu przypadła do gustu powieściowa „nowa kobieta", Harriet (takich śmiałków nie brakowało już wcześniej, ale w tym przypadku chodzi o coś poważniejszego). Mowa o ochroniarzu Makiego, Gillesie, do którego zadań należy między innymi załatwianie podejrzanych interesów szefa w Moskwie, a później także w Czarnogórze, dokąd wybiera się celem zakupienia kobiecego czasopisma, w którym matka Makiego mogłaby ponownie drukować swoje utopijno-sentymentalne teksty. Podczas tej podróży Gilles nawiązuje z Harriet romans, potraktowany przez autorkę powieści z dużą dozą ironii. Przejawia się ona przede wszystkim w tym, że Harriet uważa siebie za kobietę starą, swojego partnera Gillesa, o wiele od niej młodszego, za niezbyt atrakcyjnego, a ich miłość za „używaną":

Jesteśmy ludźmi z odzysku. I po co mi to było? A co dopiero jemu? Co chciał we mnie widzieć? Mamę? I najwyraźniej ją ma. I tę tam drugą, fuj! [Chodzi o Kwiaciarkę, tj. Mirjanę Marković - I.P.] Laskę? Nie sądzę. Nawet przez chwilę nie przeszło mi to przez myśl. Szybki numerek? Tego akurat mają w Moskwie ile chcesz, forsa, ciuchy, samochody, gówniary na to lecą. Nie pytają, czyja to własność. Moja. A nawet Juanity [komiczne imię, które Harriet nadała swojej matce - I.P.]. I mojego świętej pamięci starego, i nas wszystkich, którzy jesteśmy w dupie, płacimy tutaj za jego ciuchy i szybkie numerki. I żeby tylko. Dobra, nie mówmy o polityce, zaraz mi się robi słabo. A i tak już mi jest 
słabo. Mówię ci, nie wiem, po co mu to było, to ze mną. A co dopiero mnie? Słuchaj, ja wiem, że nigdy nie byłam laską, a teraz to jestem babą o lasce... W sumie to z niego też nie jest żadne ciacho (Đurđević 2016: 224).

Gordić-Petković pisze, że powieść wieńczy „swego rodzaju komiczno-sentymentalne spełnienie" (Gordić-Petković 2017: 79). I rzeczywiście, w końcu Harriet zdobywa partnera, a utwór przybiera, obok innych wykorzystanych w nim matryc gatunkowych, formę historii miłosnej z ironicznym, a jednak szczęśliwym zakończeniem. Ironię można dostrzec w tytule przedostatniego rozdziału. Słowa „happy end" zostały napisane cyrylicą, pomimo że książkę wydrukowano alfabetem łacińskim, po nich zaś pojawia się słowo zapewne: „Хепи енд - zapewne”, pozostawiające czytelnika w niepewności. W epilogu Đurđević jako autorka dziękuje Brankowi Mladenoviciowi za zmotywowanie jej do ukończenia powieści: "Tak oto, wyprosiwszy Autora o partnera seksualnego dla Harriet, sprawił on, że inspektor stała się wreszcie spetniona kobieta w średnim wieku" (Đurđević 2016: 238, kursywa pochodzi od autorki). Tuż przed zakończeniem powieści po raz pierwszy ujawnione zostaje prawdziwe imię Harriet, zawierające ten sam rdzeń, który jest w słowie kochać [ljubiti - jęz. serbski]: Ljubinka. W ten sposób niezależność Harriet i jej niezgoda na reprodukowanie wzorca patriarchalnego ulega demistyfikacji. W ostatnim zdaniu powieści, w odpowiedzi na pytanie Gillesa o to, czy faktycznie ma na imię Ljubinka, bohaterka potwierdzając ten fakt, skromnie spuszcza wzrok niczym Milica, bohaterka pieśni ludowej Serbska dziewczyna, dla której skierowanie spojrzenia „ku ziemi” jest sygnałem panieńskiej cnoty. Na poziomie metanarracyjnym gest ten wywołuje w czytelniku stan niepewności, czy szczęśliwe zakończenie nie oznacza dla Harriet końca kariery powieściowej i przemiany w zwyczajną, nieciekawą literacko Ljubinkę.

Uprzywilejowując optymizm i radość życia, powieści Đurđević sytuują się poza głównym nurtem serbskiej czy nawet, jak można stwierdzić bez zbytniej przesady, europejskiej tradycji literackiej, w której pisarze tacy jak François Rabelais czy Laurence Sterne stanowią wyjątki potwierdzające regułę. O powieści Bunker Swing Vrbavac napisała, odnosząc tę tezę do całej twórczości Đurđević:

Swoboda ducha jest właśnie tą nutą optymizmu i siły, która niestrudzenie daje o sobie znać we wszystkich powieściach tej autorki. Tym samym łatwo jest oddalić wszelkie zarzuty dotyczące braku zaangażowania w prozie Đurđević lub, ujmując problem bardziej precyzyjnie, programowego unikania przez nią patosu ważkich tematów społecznych, politycznych i historycznych. Eros, tak wyraźnie tutaj akcentowany, czy inaczej mówiąc wola życia i umiejętność przezwyciężania Tanatosa mocą własnych chęci i sił, o czym pośrednio traktuje ta książka, jest bowiem największą mądrością, którą niewielu potrafi bez trudu zdobyć i przyswoić (Vrbavac 174). 
Powieść Odlazak u Jolki Palki nie zawiera nawet wspomnianego powyżej defek$\mathrm{tu}$, polegającego na braku ambicji epokowych. Autorka nie tylko nie unika wielkich tematów (nie porusza ich jednak w sposób przesadnie ostentacyjny, co skutkowałoby literacką pretensjonalnością), ale nawet pogłębia refleksję nad nimi. $\mathrm{W}$ ten sposób udaje się jej obalić mit literatury komicznej jako mniej wartościowej. W osobie Đurđević literatura serbska zyskała autorkę i nowego klasyka, którego status zostanie potwierdzony w przyszłości, uwolnionej od literackich przesądów.

\section{Ttum. Magdalena Maszkiewicz Przekład przejrzała: Sylwia Nowak-Bajcar}

\section{BIBLIOGRAFIA}

Barzut, Dragoslava. „Igre naše nasušne“. Polja 448 (2007). S. 117-119.

Beleslijin, Dragana. „Preživela je!“. Polja 457 (2009). S. 185-187.

Brebanović, Predrag. „Ima li života posle smrti? Sudbina autorske instance u naratološkoj raspravi“. Zbornik Matice srpske za knjižeunost i jezik 1-2 (2001). S. 179-196.

Đurđević, Mirjana. Treći sektor: ili sama žena u tranziciji. Beograd: Knjižara Žagor, 2001.

Đurđević, Mirjana. Prvi, drugi, treći čovek: srpske legende. Zrenjanin: Agora, 2008.

Đurđević, Mirjana. Bremasoni. Beograd: Laguna, 2011.

Đurđević, Mirjana. Leš u fundusu. Beograd: Laguna, 2012.

Đurđević Mirjana, Mlađenović Branko. Bunker Swing. Beograd: Laguna, 2013.

Đurđević, Mirjana. Odlazak u Jolki Palki: ili Lažna uzbuna u Aleji zaslužnih. Beograd: Laguna, 2016.

Gordić-Petković, Vladislava. „Identitet, jezik i socijalna stratifikacija: Kako ženska književnost podriva poredak“. Izazovi identiteta: Rod između tradicije i kreacije. Ur. A. Đurić-Bosnić. Novi Sad: Centar za interkulturnu komunikaciju, 2016. S. 87-96.

Gordić-Petković, Vladislava. „Vreme i semantika (dugo)večnosti u savremenoj srpskoj i anglofonoj prozi“. Jezik, književnost, vreme: Književna istraživanja. Ur. V. Lopičić, B. Mišić-Ilić. Niš: Filozofski fakultet, 2017. S. 71-81.

Hutcheon, Linda. A Poetics of Postmodernism: History, Theory, Fiction. New York and London: Routledge, 1988.

Mandić-Spasojević, Neda. „Harijetin tok svesti“. Gradina 35-36 (2010). S. 239-250.

McHale, Brian. Powieść postmodernistyczna. Przeł. Maciej Płaza. Kraków: Wydawnictwo Uniwersytetu Jagiellońskiego, 2012.

Sapožničenko, Galja. „Prljava inspektorka Harijeta“. Sveske 84 (2007). S. 67-70.

Vrbavac, Jasmina. „Nepretenciozno zasmejavanje“. Polja 484 (2013). S. 172-174. 
